\title{
Historical synthesis and marxism in the work of Emília Viotti da Costa between the 1960's and the 1980's
}

\section{Clara Monteiro Schuartz ${ }^{\star}$, Thiago Lima Nicodema.}

\begin{abstract}
The research proposed intends to analyse the trajectory of historian Emilia Viotti da Costa from the perspective of history of historiography and theory of Brazilian history. Therefore the analysis is based on two of the author's works from the decades of 1960/1970: "Da senzala à colônia",1966; "Da monarquia a república", 1977; that approach historical synthesis within the works of Emília Viotti da Costa, a relevant author when it comes to discussions about historiography and about slavery and the shaping of Brazil's Republic.
\end{abstract}

\section{Key words: \\ Marxism; History of historiography; Women}

\section{Introduction}

Since the author writes from the perspective of Brazilian marxism, this research aims to understand how she relates marxism to the construction of synthesis, the legacy of the great synthetic essays written during the 1930s. Historical synthesis is perceived on this paper as the effort to create historical work that encompasses a bigger understanding of historical processes, and doesn't limit itself to the enumeration and organisation of the chronology of historical facts, characteristics that are somehow present in the works of Viotti.

From the analysis of the way the author appropriates of marxism, influences from the historical essays from the 1930s and her condition as a woman, historian and persecuted individual during the military dictatorship, this paper aims to understand how these factors contributed to the construction of her work, relating them to her revision works produced in the 1980s, and therefore inserting the author into the universe of the history of historiography, that still lacks analysis and research on works produced by Brazilian women.

With these questions in mind, this research is based mostly on Viotti's reflections in the essays $A$ dialética invertida: 1960-1990 and Estrutura versus Experiência Novas tendências na história do movimento operário e das classes trabalhadoras na América Latina: o que se perde e o que se ganha. These reflections show the importance of a critical perspective towards synthetic historiography through new approaches to the study of Brazilian history, which began in the 1980s and were greatly influenced by Michel Foucault and E.P Thompson. This research also aims to reinforce the relevance of synthesis and dialectics in a time when historiography has a fragmented point of view on historical processes. In addition, the study of women is very relevant in the field of history of historiography, as defended by Maria da Gloria de Oliveira. According to her research and analysis, that is a field where academic work about women is extremely scarce.

The aim of this research is to understand how the work of Emília Viotti da Costa, starting with her works $\mathrm{Da}$ senzala à colônia and Da monarquia à república, is characterised by the creation of works of historical synthesis, which are related to her status as an exiled university teacher and USP's marxist researcher during the second half of the 20th century.

\section{Results and Discussion}

Since it is situated in the domain of history of historiography, this research is based on the analysis of historical processes through the study of works produced within the field of historiography: historical texts are used as pieces of evidence and sources, testimonies of a temporal historical reality, tools to analyse historical periods that reveal themselves through the ruptures and continuities in and outside of historical production.

On what concerns marxism, defended by the author in her work, one of the most important theoretical dialogues present in her research are the works of Jean Paul Sartre. Viotti's references to Sartre appear in the way the author defends the use of dialectic in her texts from the 1980s, and in her articulation of the subjects' experience with the totalizing character of the marxist materialist theory through the course of history. Through its defense of existentialist marxism from the 1960s and 70s, the affirmation made by Jean Paul Sartre about the relationship between private and universal brings up some important questions stated by Emília Viotti in the realm of this research:

The double movement proposed by Sartre in looking both to the fact and to its totalization is an important movement to observe in the construction of Emília Viotti's syntheses, and it is the analysis method used in this project. The importance of particularity, defended in her revision texts from the 1980s, appears in Sartre's argumentation as experiences that hold originality, and therefore must be understood as singular facts inserted in the context of material structure.

\section{Conclusions}

The results of this research are still ongoing, given that the research has been initiated recently. The first results and conclusions will therefore come from the analysis of Viotti's personal archives, located at the University of São Carlos, and from interviews with researchers close to Viotti, as well as from this research's initial bibliography, the works Da Monarquia à República and Da Senzala à Colônia.

\section{Acknowledgement}

I would like to thank my advisor Thiago Lima Nicodemo and FAPESP that made this research possible 